\title{
Hymenoptera associated with conilon coffee crops in Espírito Santo state, Brazil, with emphasis on the families Diapriidae, Platygastridae and Scelionidae
}

\author{
Bruno Garcia de Oliveira ${ }^{1}$, Jose Luis Benavides-López ${ }^{(\mathbb{B}}$, Diego Galvão de Pádua ${ }^{1}$ (D)
}

'Instituto Nacional de Pesquisas da Amazônia/INPA, Manaus, AM, Brasil

${ }^{2}$ Institut de Systématique, Evolution et Biodiversité/ISYEB, Muséum national d'Histoire naturelle/CNRS, Sorbonne Université/EPHE, Université des Antilles, Paris, France Contact authors: brunogaoli@gmail.com, jose.benavides-lopez@edu.mnhn.fr, paduadg@gmail.com

Received in January 28, 2020 and approved in October 26, 2020

\section{ABSTRACT}

Information about parasitoid wasp fauna can help determine the most appropriate methods for maintaining the ecological balance in agroecosystems, as these organisms are efficient natural enemies of various agricultural pests. The aim of this study was to survey the Hymenoptera families in conilon coffee plantations intercropped with other crops, focusing on the Diapriidae, Platygastridae and Scelionidae families, in order to determine wasps that could possibly act as biological controls. The study was carried out in eight conilon coffee farms located in three municipalities (Linhares, Marilândia and Sooretama) in Espírito Santo state, Brazil, with field samples collected in May (dry season) and December (rainy season) 2014. Were collected 1084 Hymenoptera specimens distributed in 10 superfamilies and 25 families. Fourteen genera of Scelionidae were collected, with Telenomus (34\%), Idris (15\%), Trissolcus (14\%) and Ceratobaeus (10\%) as the most abundant genera; seven genera of Diapriidae were collected with Doliopria (41\%), Basalys (22\%) and Trichopria (20\%) as the most abundant; and two genera of Platygastridae were collected: Leptacis (52\%) and Synopeas (14\%). The highest abundance of wasp individuals was found in coffee intercropped with rubber trees. Intercropped coffee cultivation could potentially attract more natural enemies, as well as egg parasitoids that are promising biological controls.

Key words: Biodiversity; Biological control; Entomology; Parasitoid wasps.

\section{INTRODUCTION}

Coffee makes up a huge portion of the Brazilian economy. From January to July 2020, Brazil exported about 23 million bags of coffee to 118 countries around the globe, generating an exchange revenue of US\$ 3 billion (Conselho dos Exportadores de Café do Brasil, CECAFE, 2020). The two species of planted coffee are arabica (Coffea arabica L.) and conilon (Coffea canephora Pierre ex A. Froehner). Espírito Santo state produces $63 \%$ of the total conilon coffee from Southeastern Brazil, containing about 266 thousand hectares of plantations (Companhia Nacional de Abastecimento, CONAB, 2017). Conilon coffee crops present remarkable advantages as adaptation to higher average temperatures $\left(23 \pm 3{ }^{\circ} \mathrm{C}\right)$ and stronger disease resistance (Souza et al., 2004).

Coffee crops intercropped with trees (e.g., rubber trees) are associated with less extreme weather conditions such as lower incidence of solar radiation (Partelli et al., 2014). Additionally, these species can provide extra income sources of farmers by providing products such as food, firewood or fibers (Salgado et al., 2004; Nicoleli; Moller, 2006; Silva et al., 2012). These associations improve ecosystem functioning, aid in natural soil fertilization processes without additional chemical mixtures and enrich the fauna and flora diversity. This increase in flora diversity also favors the presence of pollinators and natural enemies that help control pests; thus, resulting in fewer chemical interventions to control them (Schroth et al., 2004).

In this context, Hymenoptera is an essential component of agroecosystems. This order contains families that act in two key niches: bee pollination and biological control of predator groups such as wasps, ants and parasitoids, which control and reduce pests at all developmental stages - egg, larva, pupa and adult (Gauld; Bolton, 1988; La Salle, 1993; Parra et al., 2002).

Egg parasitoids are one of the effective natural enemies of agricultural pests and have been successfully used for many decades as biological controls (Mills, 2010; Ballal, 2013). According to Mills (2010), six families of parasitic Hymenoptera have been used as classical biological controls of agricultural insect pests: families with exclusively egg parasitoids (Mymaridae, Scelionidae, and Trichogrammatidae); and families with some species of egg parasitoids (Elasmidae, Encyrtidae, Eulophidae and Platygastridae).

Research about egg parasitoids has received a lot of attention for two reasons: a) the relative ease in which they can be mass reared; and b) the fact that they not only attack host eggs, but also kill hosts in the egg stage, preventing damage to crops (Hassan, 1993; Parra; Zucchi, 2004). These parasitoids have been used to control many insect pests that infest crops such as cotton, grape, sorghum, soybean, sugar cane and tomato (summarized in Lenteren; Bueno, 2003).

Additionally, information about the Hymenoptera present in coffee crops is important, for developing biological control 
programs, to the extent as it is known which families are present at the crop. Thus, the objective of this work was to survey the Hymenoptera families in conilon coffee plantations intercropped with other crops, focusing on the families that have been poorly explored in agroecosystem studies: Diapriidae, Platygastridae and Scelionidae, in order to determine which wasps could potentially be used as biological controls, particularly parasitoids of Scelionidae eggs (Gauld; Bolton, 1988).

\section{MATERIAL AND METHODS}

The study was carried out in Espírito Santo state (Brazil), in three municipalities (Linhares, Marilândia and Sooretama) and eight conilon coffee farms. Among these coffee farms, coffee plants were intercropped with different associated crops (Figures 1-4), with different spacing between plants and associated crops (Table 1). The weather in the region is dry in the winter and rainy in the summer season, and classified as tropical, with average annual precipitation of 151-250 mm, $24-27^{\circ} \mathrm{C}$ average temperature and $74 \%$ relative humidity
(Instituto Capixaba de Pesquisa, Assistência e Extensão Rural, INCAPER, 2020). Field samples were collected in May (dry season) and December (rainy season) of 2014.

A 14-inch sweep net made of canvas or other linenlike fabric with a metallic structure reinforcing at the end was used to collect samples. Five blocks of 10 plants were sampled from each farm and the upper third portion of the coffee plant was swept. Sweeping time on each plant was not timed. The contents of the net were deposited in a plastic bag with paper strips and a modified lethal chamber (glass container with a cotton wick soaked in ethyl acetate). The insects were kept in the bags for two hours. The material was sorted at the entomology laboratory of the Instituto Capixaba de Pesquisa, Assistência Técnica e Extensão Rural (INCAPER), in Linhares (Espírito Santo state). Then, they were transported in entomological blankets with the field information (date, type of agroecosystem, collector, location and geo-references), and stored in alcohol containers that were sent to the Instituto Nacional de Pesquisas da Amazônia (INPA), in Manaus (Amazonas state) for identification.
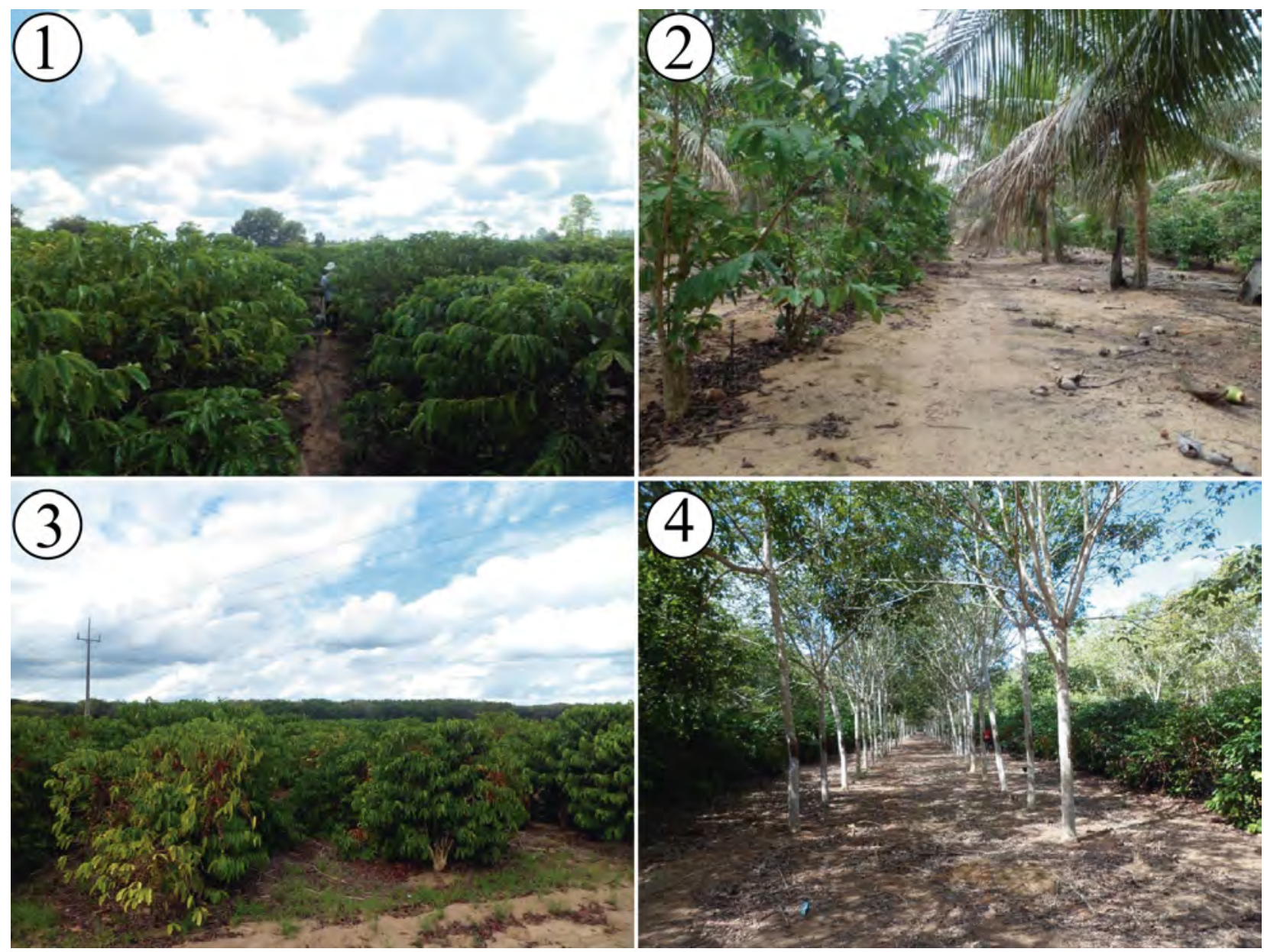

Figure 1: Farms and coffee crop and associated crops at Sooretama municipality, Espírito Santo state, Brazil: 1-2, São Francisco Farm: 1) coffee crop; 2) coffee and coconut (Cocos nucifera) crop. 3-4, Ouro Preto Farm, Sooretama municipality: 3) coffee crop; 4) coffee and ruber tree (Hevea brasiliensis) crop. 

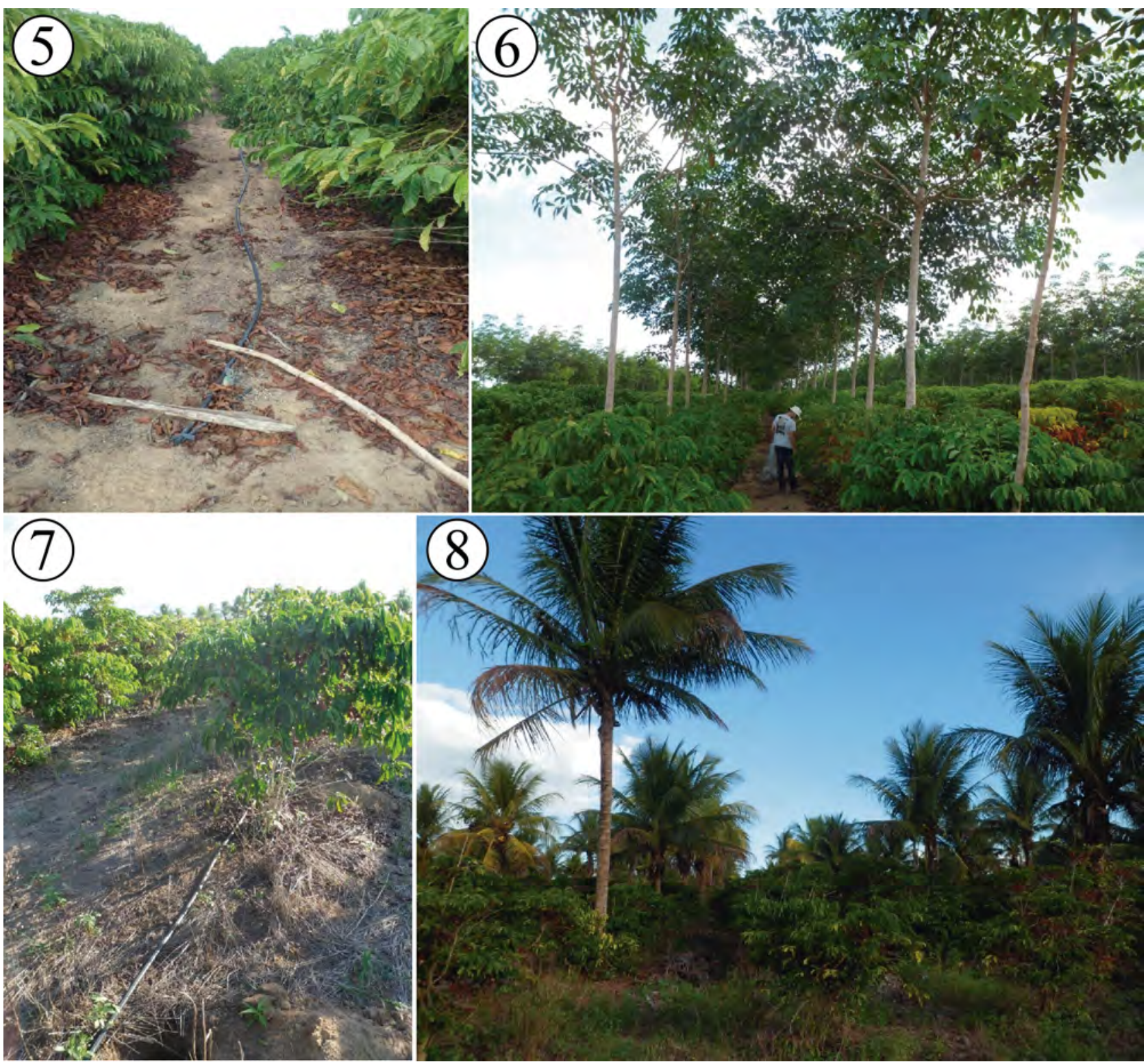

Figure 2: Farms and coffee crop and associated crops at Espírito Santo state, Brazil: 5-6, Venturine Farm, Sooretama municipality: 5) coffee crop; 6) coffee and ruber tree (Hevea brasiliensis) crop. 7-8, Boa Vista Farm, Linhares municipality: 7) coffee crop; 8) coffee and coconut (Cocos nucifera) crop.

Hymenoptera were identified under a stereomicroscope (model Nikon SMZ645) with a 2x magnifying glass (model Nikon G-AL). To identify the families, the taxonomical keys proposed by Goulet and Huber (1993) were used, and to identify the genera of Diapriidae, Platygastridae and Scelionidae families, the keys proposed by Masner and Garcia (2002), Masner and Huggert (1989) and Masner (1976) were used respectively. The generic identifications of some Platygastridae specimens were not possible because they were destroyed during the sweep sampling process.

Vouchers were deposited (in alcohol) at the Universidade Federal de Viçosa (curator: Paulo S. Fiuza), Minas Gerais state, Brazil.

\section{RESULTS AND DISCUSSION}

A total of 1084 Hymenoptera specimens distributed in ten superfamilies and 25 families were collected (Table 2). The most abundant families were Trichogrammatidae (14\%), Eulophidae (13\%), Braconidae (10\%) and Scelionidae (10\%). The coffee intercropped with rubber trees presented the highest abundance of Hymenoptera (32\%), followed by coffee with coconut trees (22\%) and coffee with cedar trees (21\%) (Figure 5). Likewise, family richness was also higher in coffee with rubber trees (19 families), followed by coffee with coconut (18) and monoculture coffee (16). 


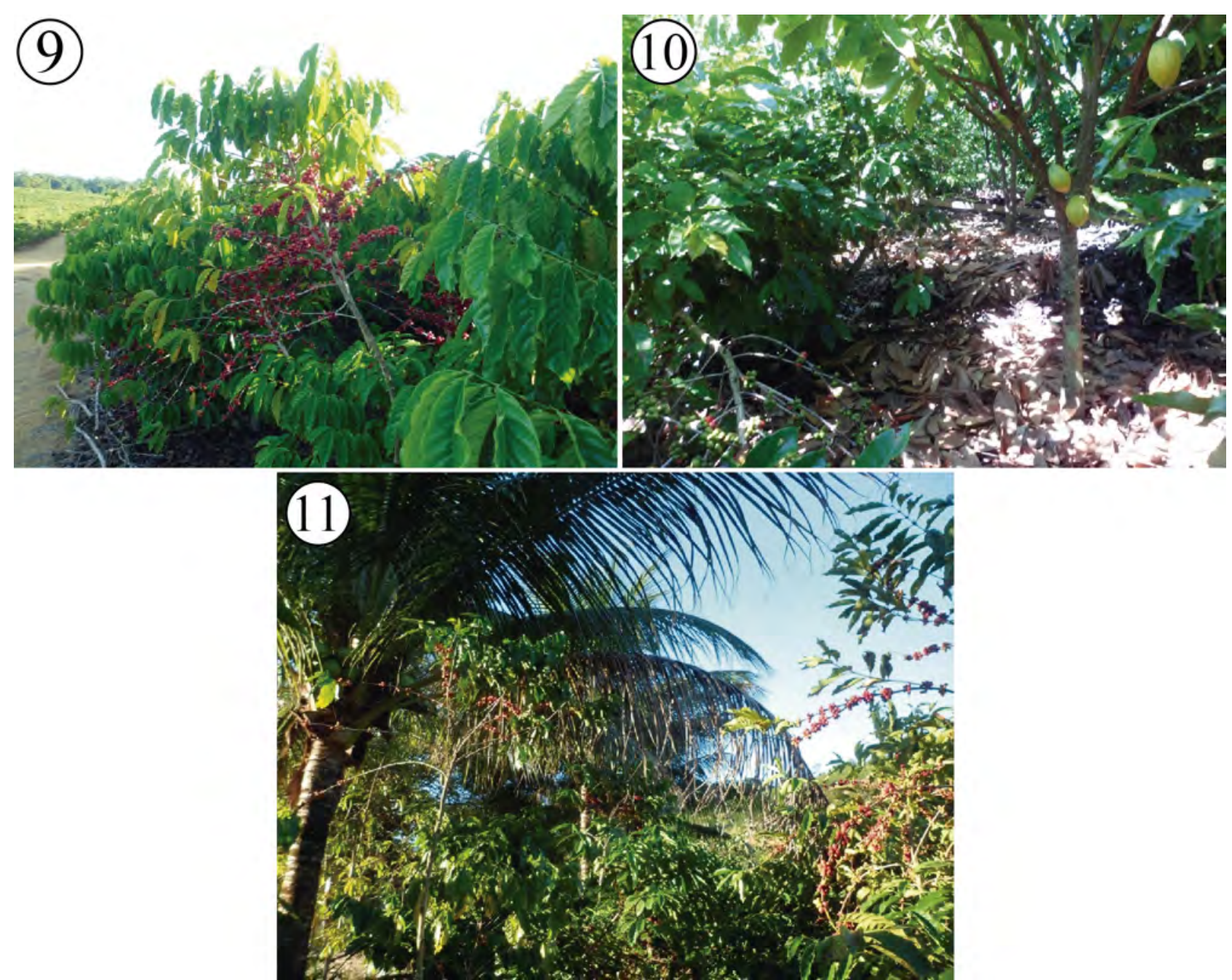

Figure 3: Farms and coffee crop and associated crops at Liberdade Farm, Marilândia municipality, Espírito Santo state, Brazil: 9) coffee crop; 10) coffee and cocoa (Theobroma cacao) crop; 11) coffee and coconut (Cocos nucifera) crop.

Intercropping other plants with coffee could increase arthropod diversity in the local environment due to microhabitat variety. For example, Perdoná, Cruz and Fischer (2013) have reported that the shading of coffee crops associated with macadamia (Macadamia intergrifolia Maiden \& Betche) reduced scalding (Rhynchosporium secalis (Oudem) J.J. Davis) and freezing, the incidence of harm by winds, defoliation, with fewer attacks by the coffee leaf miner (Leucoptera coffeella (Guérin-Mèneville \& Perrottet)), weeds, and increased nutrient cycling and the presence of natural pests and disease controllers.

Compared to the survey of parasitoid fauna in arabica coffee crops (Coffea arabica L.), which was collected using Moericke traps in inland São Paulo, the families Encyrtidae, Scelionidae, Ichneumonidae, Mymaridae and Braconidae were the most abundant, respectively (Perioto et al., 2004). Using Malaise traps in Chapada Diamantina (Bahia state), Ichneumonidae, Braconidae, Eulophidae, Mymaridae and Pteromalidade were the most abundant families, respectively (Palma-Santos; Pérez-Maluf, 2010). Additionally, Encyrtidae,
Diapriidae, Ceraphronidae, Platygastridae and Braconidae were the most abundant families, respectively, in Moerecke traps used in organic coffee crops from Minas Gerais (Ferreira; Silveira; Haro, 2013). Therefore, the differences in the trap type, regions, and the presence or absence of associated crops could affect the abundance of Hymenoptera fauna diversity.

In this study, Trichogrammatidae was most abundant in coffee monoculture and coffee associated with coconut (Table 2). Such abundance is related to the egg mass collected from individuals of the same morphospecies. This occurs in polyembryonic parasitoids such as Trichogrammatidae and Encyrtidae, in which more than 10 parasitoid wasps can emerge from one single host egg (Strand, 2009; Segoli et al., 2010). Natural enemies with this habit are very efficient biological controls, as they directly attack eggs and eliminate pests before they cause any losses to farmers/growers.

Eulophidae were most abundant in the coffee intercropped with cedar (Table 2). This family has an extremely varied life habit, presenting the most species among 
Chalcidoidea (Fernández, 2006). The species Horismenus cockerelli Blanchard has been registered as a parasitoid of the “coffee caterpillar” Eacles imperialis (Walker) (Lepidoptera) (Silva et al., 1968) and Melo et al. (2007) have registered Cirrospilus neotropicus (Diez \& Fidalgo), Closterocerus coffeellae (Ihering), Horismenus aeneicollis (Ashmead) and Neochrysocharis coffeae (Ihering) parasitizing "the coffee leaf miner”, Leucoptera coffeella (Lepidoptera: Lyonetiidae) on coffee plants in the Western and Southwestern regions of Bahia, Brazil.

Into the coffee intercropped with rubber trees, the Braconidae family was most abundant (Table 2). Species of Tephritidae flies have been reported as pests that damage coffee crops is (Camargos et al., 2015). Braconidae have been reported as excellent biological controllers of coffee pests, e.g., Diachasmimorpha longicaudata (Ashmead), which has successfully been used worldwide to decrease infestations of these dipterans (Purcell et al., 1994; Sivinski et al., 1998), and Opius bellus Gahan, which has proven to be promising in combating Anastrepha fraterculus (Wiedemann) (NúñezCampero et al., 2014). Furthermore, the braconids Macrocentrus ancylivorus Rohwer and Meteorus eaclidis Muesebeck have been reported as natural enemies of the "coffee caterpillar" Eacles imperialis (Lepidoptera) (Silva et al., 1968).

In coffee intercropped with cocoa, Scelionidae was the most abundant family (Table 2). Similarly, the genera Telenomus (Scelionidae) was the most abundant in a survey performed on cocoa crops located in Aragua state (Venezuela), and its species are associated with Hemiptera and Lepidoptera eggs (Rodríguez; Montilla, 2005). For coffee intercropped with black pepper, the Encyrtidae family was most abundant (Table 2), which is an important parasitoid of mealybug (Noyes, 2017).
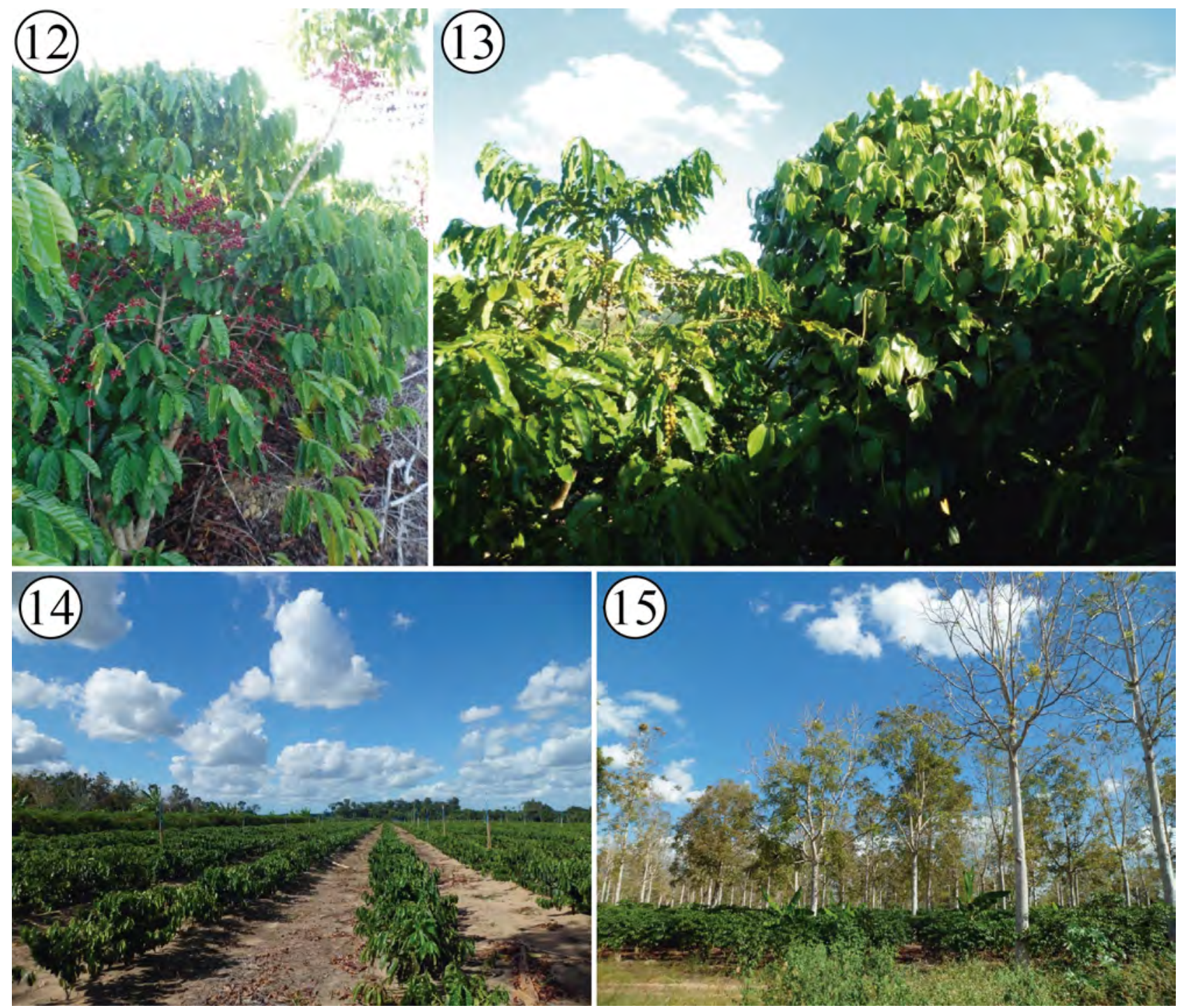

Figure 4: Farms and coffee crop and associated crops at Espírito Santo state, Brazil: 12-13, Marilândia Farm, Marilândia municipality: 12) coffee crop; 13) coffee and black pepper (Piper nigrum) crop. 14-15, Santa Luzia Farm, Sooretama municipality: 14) coffee crop; 15) coffee and cedar tree (Toona ciliata) crop. 
Table 1: Farms and their agroecosystems.

\begin{tabular}{|c|c|c|c|c|c|}
\hline Agroecosystems & Espace & Altitude & GPS & Municipality & Farm \\
\hline $\begin{array}{c}\text { Coffee (Figure 1(1)) } \\
\text { Coffee/Coconut (Cocos nucifera) (Figure 1(2)) }\end{array}$ & $2 \mathrm{x} 1$ & 86 & $\begin{array}{l}19^{\circ} 08^{\prime} 828^{\prime \prime} \mathrm{S} \\
40^{\circ} 09^{\prime} 963 ” \mathrm{~W}\end{array}$ & Sooretama & São Francisco \\
\hline $\begin{array}{c}\text { Coffee (Figure 1(3)) } \\
\text { Coffee/ruber tree (Hevea brasiliensis) (Figure 1(4)) }\end{array}$ & $2 \times 2$ & 89 & $\begin{array}{l}19^{\circ} 05^{\prime} 943^{\prime \prime} \mathrm{S} \\
40^{\circ} 10^{\prime} 00^{\prime \prime} \mathrm{W}\end{array}$ & Sooretama & Ouro Preto \\
\hline $\begin{array}{c}\text { Coffee (Figure 2(5)) } \\
\text { Coffee/Ruber tree (Hevea brasiliensis) (Figure 2(6)) }\end{array}$ & $4 \times 1$ & 96 & $\begin{array}{l}19^{\circ} 08^{\prime} 747^{\prime \prime} \mathrm{S} \\
40^{\circ} 08^{\prime} 874^{\prime \prime} \mathrm{W}\end{array}$ & Sooretama & Venturine \\
\hline $\begin{array}{c}\text { Cofee (Figure 2(7)) } \\
\text { Coffee/Coconut (Cocos nucifera) (Figure 2(8)) }\end{array}$ & $2 \mathrm{x} 1$ & 45 & $\begin{array}{l}19^{\circ} 15^{\prime} 726^{\prime \prime} \mathrm{S} \\
40^{\circ} 05^{\prime} 145^{\prime \prime} \mathrm{W}\end{array}$ & Linhares & Boa vista \\
\hline $\begin{array}{c}\text { Coffee (Figure 3(9)) } \\
\text { Coffee/Cocoa (Theobroma cacao) (Figure 3(10)) }\end{array}$ & $2 \mathrm{x} 1$ & 86 & $\begin{array}{l}19^{\circ} 24^{\prime} 267^{\prime \prime} \mathrm{S} \\
40^{\circ} 32^{\prime} 577^{\prime \prime} \mathrm{W}\end{array}$ & Marilândia & Liberdade 1 \\
\hline $\begin{array}{c}\text { Coffee (Figure 3(9)) } \\
\text { Coffee/Coconut (Cocos nucifera) (Figure 3(11)) }\end{array}$ & $2 \mathrm{x} 1$ & 86 & $\begin{array}{l}19^{\circ} 24^{\prime} 267^{\prime \prime} \mathrm{S} \\
40^{\circ} 32^{\prime} 577^{\prime \prime} \mathrm{W}\end{array}$ & Marilândia & Liberdade 2 \\
\hline $\begin{array}{c}\text { Coffee (Figure 4(12)) } \\
\text { Coffee/Black pepper (Piper nigrum) (Figure 4(13)) }\end{array}$ & $1 \mathrm{x} 1$ & 154 & $\begin{array}{l}19^{\circ} 24^{\prime} 0533^{\prime \prime} \mathrm{S} \\
40^{\circ} 32^{\prime} 633^{\prime \prime} \mathrm{W}\end{array}$ & Marilândia & Marilândia \\
\hline $\begin{array}{l}\text { Coffee (Figure 4(14)) } \\
\text { Coffee/Cedar (Toona ciliata) (Figure 4(15)) }\end{array}$ & $3 \times 1$ & 98 & $\begin{array}{l}19^{\circ} 06^{\prime} 805^{\prime \prime} \mathrm{S} \\
40^{\circ} 11^{\prime} 330^{\prime \prime} \mathrm{W}\end{array}$ & Sooretama & Santa Luzia \\
\hline
\end{tabular}

Table 2: Hymenoptera superfamilies and families sampled in coffee crops and associated crops at Espírito Santo, Brazil.

\begin{tabular}{|c|c|c|c|c|c|c|c|c|}
\hline Superfamily & Family & Total & Coffee & Coffee/coconut & Coffee/cocoa & Coffee/ruber tree & Coffee/cedar & Coffee/black pepper \\
\hline \multirow[t]{2}{*}{ Apoidea } & Apidae & 1 & 0 & 0 & 0 & 1 & 0 & 0 \\
\hline & Halictidae & 1 & 0 & 1 & 0 & 0 & 0 & 0 \\
\hline Ceraphronoidea & Ceraphronidae & 74 & 4 & 1 & 0 & 56 & 8 & 5 \\
\hline \multirow[t]{12}{*}{ Chalcidoidea } & Aphelinidae & 5 & 3 & 1 & 0 & 1 & 0 & 0 \\
\hline & Chalcididae & 7 & 3 & 4 & 0 & 0 & 0 & 0 \\
\hline & Encyrtidae & 144 & 13 & 34 & 0 & 47 & 28 & 22 \\
\hline & Eulophidae & 150 & 6 & 34 & 0 & 44 & 61 & 5 \\
\hline & Eupelmidae & 14 & 0 & 11 & 0 & 0 & 0 & 3 \\
\hline & Eurytomidae & 1 & 1 & 0 & 0 & 0 & 0 & 0 \\
\hline & Mymaridae & 45 & 3 & 12 & 0 & 16 & 13 & 1 \\
\hline & Pteromalidae & 22 & 4 & 1 & 0 & 16 & 1 & 0 \\
\hline & Signiphoridae & 9 & 0 & 3 & 0 & 6 & 0 & 0 \\
\hline & Tanaostigmatidae & 1 & 0 & 0 & 0 & 1 & 0 & 0 \\
\hline & Torymidae & 1 & 0 & 0 & 0 & 0 & 0 & 1 \\
\hline & Trichogrammatidae & 160 & 104 & 52 & 0 & 0 & 1 & 3 \\
\hline \multirow[t]{2}{*}{ Chrysidoidea } & Sclerogibbidae & 5 & 1 & 2 & 0 & 1 & 0 & 1 \\
\hline & Dryinidae & 2 & 0 & 0 & 0 & 1 & 1 & 0 \\
\hline Cynipoidea & Figitidae & 39 & 1 & 12 & 0 & 13 & 13 & 0 \\
\hline Diaprioidea & Diapriidae & 58 & 0 & 11 & 4 & 20 & 20 & 3 \\
\hline Evanioidea & Evaniidae & 6 & 1 & 0 & 0 & 4 & 1 & 0 \\
\hline \multirow[t]{2}{*}{ Ichneumonoidea } & Braconidae & 118 & 21 & 8 & 0 & 70 & 17 & 2 \\
\hline & Ichneumonidae & 2 & 1 & 1 & 0 & 0 & 0 & 0 \\
\hline \multirow[t]{2}{*}{ Platygastroidea } & Platygastridae & 50 & 10 & 18 & 2 & 16 & 4 & 0 \\
\hline & Scelionidae & 116 & 13 & 32 & 15 & 33 & 14 & 9 \\
\hline \multirow[t]{2}{*}{ Vespoidea } & Vespidae & 53 & 0 & 0 & 0 & 1 & 52 & 0 \\
\hline & Total & 1086 & 189 & 238 & 21 & 347 & 234 & 55 \\
\hline
\end{tabular}




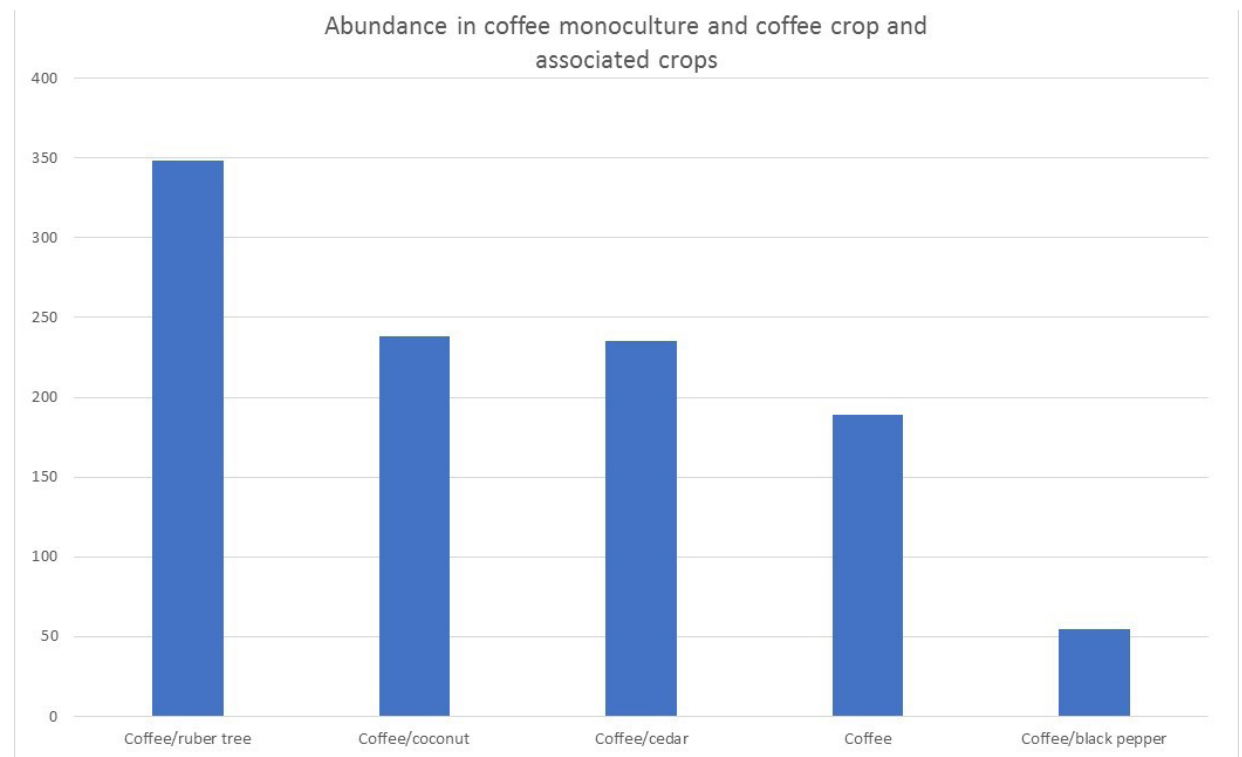

Figure 5: Hymenoptera individual abundance collected in coffee crop and associated crops at Espírito Santo, Brazil.

Fourteen genera of Scelionidae were collected, with Telenomus (34\%), Idris (15\%), Trissolcus (14\%) and Ceratobaeus (10\%) the most abundant. Among the seven genera of Diapriidae collected, the most abundant were Doliopria (41\%), Basalys (22\%) and Trichopria (20\%). Two genera of Platygastridae were collected: Leptacis (52\%) and Synopeas (14\%). Thirty four percent of Platygastridae specimens were unidentified because they were partially destroyed (Table 3). Telenomus was most abundant in coffee intercropped with rubber (53\%), then in coffee with cocoa (17\%), and could be related to coffee pests as rubber pests Erinnys ello (L.) (Santos, 2014); and cocoa pests like Scolytidae (Coleoptera) (Pérez-De La Cruz et al., 2009).

Trissolcus was most abundant in coffee with coconut (38\%) and coffee with cedar (22\%). In general, these two genera are associated with eggs from a large number of true bugs that damage agriculture (Laumann et al., 2010; Cingolani; Greco; Liljesthröm, 2014), presenting great potential in controlling this group of pests - i.e., Telenomus podisi Ashmead and Trissolcus basalis (Wollaston) associated with Hemiptera eggs as Tibraca limbativentris Stal that damages rice cultures (Riffel; Prando; Boff, 2010; Idalgo et al., 2013); Trissolcus urichi (Crawford) and T. podisi (Ashmead) associated with E. heros, which attacks cocoa, soy and other seasonal crops (Panizzi, 1997); Telenomus remus Nixon is a parasitoid of Spodoptera frugiperda (J.E. Smith) eggs, which is a pest that greatly damages corn crops (Bueno et al., 2008). In coffee crops, T. alsophilae Viereck has been reported parasitizing eggs of the coffee defoliating caterpillar Alsophila pometaria (Harr.) (Orr, 1988).
Idris and Ceratobaeus are parasitoids of Araneae oothecas that are commonly found in studies about Hymenoptera, especially in Neotropical regions (Arias-Penna, 2002; Azevedo et al., 2015).

Doliopria is a poorly studied genus, with few species in the Nearctic region and a high number of undescribed species in the tropical regions of the Americas (Masner; García, 2002). This genus presents parasitic relationships with ants from Ecitonini and Attini tribes (Masner; García, 2002). In general, Basalys and Trichopria are parasitoids of dipteran pupae (Notton, 1990; Cruz; Neutzling; Garcia, 2011), however, there are some reports of Basalys parasitizing pupae of Psila rosae F., a carrot pest (Estrada, 2008).

Among the Diapriidae collected, Trichopria is the genus with the most potential for pest control, as it is associated with Anastrepha (Wollmann et al., 2016) that attack coffee fruits and can cause considerable losses for farmers (Montes et al., 2012; Camargos et al., 2015).

Leptacis and Synopeas are parasitoids of galling dipteran (Cecidomyiidae) (Maia; Azevedo, 2009). Some species of Synopeas have been reported as important biological controls of Prodiplosis longifila Gagné in tomato (Solanum lycopersicum L.) crops in Colombia (Mahecha et al., 2018).

The presence of diverse Hymenoptera parasitoid groups is a good indication that coffee intercropped with other crops could be promising for biological control of coffee pests. Considering the sampling method, this could be due to the diversity of Scelionidae and Diapriidae. 
Table 3: Scelionidae, Diapriidae and Platygastridae genera. Collected in coffee crop and associated crops at Espirito Santo, Brazil.

\begin{tabular}{|c|c|c|c|c|c|c|c|c|}
\hline Family & Genus & Total & Coffee & $\begin{array}{l}\text { Coffee/ } \\
\text { coconut }\end{array}$ & $\begin{array}{c}\text { Coffee/ } \\
\text { cocoa }\end{array}$ & $\begin{array}{c}\text { Coffee/ ruber } \\
\text { tree }\end{array}$ & $\begin{array}{l}\text { Coffee/ } \\
\text { cedar }\end{array}$ & $\begin{array}{c}\text { Coffee/ } \\
\text { black pepper }\end{array}$ \\
\hline \multirow{15}{*}{ Scelionidae } & Probaryconus & 1 & 1 & 0 & 0 & 0 & 0 & 0 \\
\hline & Chromoteleia & 1 & 0 & 0 & 1 & 0 & 0 & 0 \\
\hline & Calliscelio & 1 & 0 & 1 & 0 & 0 & 0 & 0 \\
\hline & Oethecoctonus & 1 & 0 & 1 & 0 & 0 & 0 & 0 \\
\hline & Baryconus & 2 & 1 & 1 & 0 & 0 & 0 & 0 \\
\hline & Cremastobaeus & 2 & 1 & 0 & 0 & 0 & 0 & 1 \\
\hline & Scelio & 2 & 1 & 0 & 0 & 1 & 0 & 0 \\
\hline & Odontacolus & 3 & 0 & 1 & 1 & 1 & 0 & 0 \\
\hline & Synopeas & 7 & 3 & 2 & 0 & 2 & 0 & 0 \\
\hline & Gryon & 12 & 1 & 8 & 3 & 0 & 0 & 0 \\
\hline & Ceratobaeus & 13 & 1 & 1 & 0 & 7 & 0 & 4 \\
\hline & Trissolcus & 18 & 2 & 7 & 2 & 1 & 4 & 2 \\
\hline & Idris & 19 & 1 & 7 & 0 & 1 & 9 & 0 \\
\hline & Telenomus & 41 & 4 & 5 & 7 & 22 & 1 & 2 \\
\hline & Total & 123 & 16 & 34 & 14 & 35 & 14 & 9 \\
\hline \multirow{8}{*}{ Diapriidae } & Acanthopria & 2 & 0 & 0 & 0 & 1 & 1 & 0 \\
\hline & Basalys & 13 & 0 & 7 & 0 & 3 & 3 & 0 \\
\hline & Coptera & 5 & 0 & 0 & 0 & 4 & 0 & 1 \\
\hline & Doliopria & 24 & 0 & 1 & 0 & 9 & 13 & 1 \\
\hline & Mitopria & 1 & 1 & 0 & 0 & 0 & 0 & 0 \\
\hline & Spilomicrus & 1 & 0 & 0 & 0 & 0 & 1 & 0 \\
\hline & Trichopria & 12 & 0 & 0 & 2 & 3 & 6 & 1 \\
\hline & Total & 58 & 1 & 8 & 2 & 20 & 24 & 3 \\
\hline \multirow{4}{*}{ Platygastridae } & Synopeas & 7 & 3 & 2 & 0 & 2 & 0 & 0 \\
\hline & Leptacis & 26 & 2 & 5 & 2 & 13 & 4 & 0 \\
\hline & Total & 33 & 5 & 11 & 0 & 1 & 0 & 0 \\
\hline & Damaged & 17 & 10 & 18 & 2 & 16 & 4 & 0 \\
\hline \multicolumn{2}{|c|}{ TOTAL (general) } & 231 & 32 & 71 & 18 & 72 & 42 & 12 \\
\hline
\end{tabular}

\section{CONCLUSIONS}

Intercropped coffee could potentially attract more natural enemies, as well as egg parasitoids that are promising for biological control. Herein, several genera of Platygastridae, Scelionidae and Diapriidae were recorded in this agroecosystem and their potential as biological controls is reported for the first time.

\section{ACKNOWLEDGMENTS}

We thank reviewers for their critical reviews and suggestions on this manuscript. We also thank to owners of the farms where the collections were made, and to all people of the Instituto Capixaba de Pesquisa, Assistência Técnica e
Extensão Rural (INCAPER) for contributing to logistics and human resources. Thanks to Karine Schoeninger who identified the Chalcidoidea wasps. This study was financed in part by the Coordenação de Aperfeiçoamento de Pessoal de Nível Superior - Brasil (CAPES), Finance Code 001 (D.G. Pádua).

\section{REFERENCES}

ARIAS-PENNA, T. M. Lista de los géneros y espécies de la superfamilia platygastroidea (Hymenoptera) de la región neotropical. Biota Colombiana, 3(2):215-133, 2002.

AZEVEDO, C. O. et al. Checklist of the genera of hymenoptera (Insecta) from Espírito Santo state, Brazil. Boletim do Museu de Biologia Mello Leitão, 37(3):313343, 2015. 
BALLAL, C. R. Other egg parasitoids: Research for utilisation. In: SITHANANTHAM, S. et al. (eds) Biological control of insect pests using egg parasitoids. Springer, India. 2013. 435p.

BUENO, R. C. O. F. et al. Biology and thermal requirements of Telenomus remus on fall armyworm Spodoptera frugiperda eggs. Ciência Rural, 38(1):1-6, 2008.

CAMARGOS, M. G. et al. Moscas-das-frutas (Diptera: Tephritidae) em cafezais irrigados no Norte de Minas Gerais. Coffee Science, 10(1):28-37, 2015.

CINGOLANI, M. F.; GRECO, N. M.; LILJESTHRÖM, G. G. Effect of Telenomus podisi, Trissolcus urichi, and Trissolcus basalis (Platygastridae) Age on attack of Piezodorus guildinii (Hemiptera: Pentatomidae) eggs. Environmental Entomology, 43(2):377-383, 2014.

COMPANHIA NACIONAL DE ABASTECIMENTO CONAB. Acompanhamento da safra brasileira de café - Safra 2017. 4(4):1-84. 2017.

\section{CONSELHO DOS EXPORTADORES DE CAFÉ DO} BRASIL - CECAFE. Relatório mensal: julho 2020: Resumo das exportações de café. 2020. Available in: < https://www.cecafe.com.br/site/wp-content/uploads/ graficos/CECAFE-Relatorio-Mensal-JULHO-2020.pdf $>$. Access in: August, 18, 2020.

CRUZ, P. P.; NEUTZLING, A. S.; GARCIA, F. R. M. Primeiro registro de Trichopria anastrephae, parasitoide de moscas-das-frutas, no Rio Grande do Sul. Ciência Rural, 41(8):1297-1299, 2011.

ESTRADA, C. I. N. Control biológico de insectos: Un enfoque agroecológico. Medellin, Editorial Universidad de Antioquia. 2008. 282p.

FERNÁNDEZ, F. Sistemática de los himenópteros de la región neotropical: Estado del conocimiento y perspectivas. In: FERNÁNDEZ, F.; SHARKEY, M. J. (eds) Introducción a los Hymenoptera de la Región Neotropical. Sociedad Colombiana de Entomología y Universidad Nacional de Colombia, Bogotá D.C. 2006. 925p.

FERREIRA, F. Z.; SILVEIRA, L. C. P.; HARO, M. M. Families of hymenoptera parasitoids in organic coffee cultivation in Santo Antonio do Amparo, MG, Brazil. Coffee Science, 8(1):1-4, 2013.

GAULD, I. D.; BOLTON, B. The hymenoptera. Oxford, Oxford University. 1988. 332p.

GOULET, H.; HUBER, J. T. Hymenoptera of the world: An identification guide to families. Ottawa, Agriculture Canada Publication. 1993. 680p.
HASSAN, S. A. The mass rearing and utilization of Trichogramma to control lepidopterous pests: Achievements and outlook. Pest Management Science, 37(4):387-391, 1993.

IDALGO, T. D. N. Parasitismo de ovos de Tibraca limbativentris stal (Hemiptera: Pentatomidae) em lavouras de arroz irrigado, Endorado do Sul, RS. Arquivos do Instituto Biológico, 80(4):453-456, 2013.

INSTITUTO CAPIXABA DE PESQUISA, ASSISTÊNCIA E EXTENSÃO RURAL - INCAPER. Nota técnica: previsão climática mensal para o espírito santo: janeiro/2020. 2020. Available in: <https://meteorologia. incaper.es.gov.br/Media/Hidrometeorologia/documentos/ Prog_2020_T01.pdf >. Access in: August, 19, 2020.

LA SALLE, J. Parasitic hymenoptera, biological control and biodiversity. In: LA SALLE, J.; GAULD, I. D. (eds). Hymenoptera and biodiversity. Wallingford, CAB International. 1993. 348p.

LAUMANN, R. A. et al. Egg parasitoid wasps as natural enemies of the neotropical stink bug Dichelops melacanthus. Pesquisa Agropecuária Brasileira, 45(5):442-449, 2010.

LENTEREN, J. C. Van; BUENO, V. H. P. Augmentative biological control of arthropods in Latin America. BioControl, 48:123-139, 2003.

MAHECHA, L. M. H. et al. Parasitoids of Prodiplosis longifila gagné (Diptera: Cecidomyiidae) and other cecidomyiidae species in Colombia. Acta Agronómica, 67(1):184-191, 2018.

MAIA, V. C.; AZEVEDO, M. A. P. Micro-himenópteros associados com galhas de cecidomyiidae (Diptera) em restingas do Estado do Rio de Janeiro (Brasil). Biota Neotropica, 9(2):151-164, 2009.

MASNER, L. Revisionary notes and keys to world genera of scelionidae (Hymenoptera: Proctotrupoidea). The Memoirs of the Entomological Society of Canada, 108(S97):1-87. 1976.

MASNER, L.; HUGGERT, L. World review and keys to genera of the subfamily inostemmatinae with reassignment of the taxa to the platygastrinae and sceliotrachelinae (Hymenoptera: Platygastridae). The Memoirs of the Entomological Society of Canada, 121(S147):3-216. 1989.

MASNER, L.; GARCÍA, J. L. The genera of diapriinae (Hymenoptera: Diapriidae) in the new world. Bulletin of the American Museum of Natural History, 268:1-125, 2002. 
MELO, T. L. et al. Comunidades de parasitoides de Leucoptera coffeella (Guérin-Mèneville \& Perrottet, 1842) (Lepidoptera: Lyonetiidae) em cafeeiros nas regiões Oeste e Sudoeste da Bahia. Ciência e Agrotecnologia, 31(4):966-972, 2007.

MILLS, N. Chapter 15. Egg parasitoids in biological control and integrated pest management. In: CÔNSOLI, F. L.; PARRA, J. R. P.; ZUCCHI, R. A. (eds) Egg parasitoids in agroecosystems with emphasis on Trichogramma. Progress in Biological Control book series (volume 9), Springer, Dordrecht. 2010. 479p.

MONTES, S. M. N. M. et al. Moscas-das-frutas em cultivares de cafeeiros de Presidente Prudente, SP. Coffee Science, 7(2):99-109, 2015.

NICOLELI, M.; MOLLER, H. D. Análise da competitividade dos custos do café orgânico sombreado irrigado. Custos e Agronegócio, 2(1):29-44, 2006.

NOTTON, D. G. Some diptera host recrods for species of Basalys and Trichopria (Hym., Diapriidae).

Entomologist's Monthly Magazine, 127:123-126, 1990.

NOYES, J. S. Universal chalcidoidea database. 2017. World Wide Web electronic publication. Available in: <http:// www.nhm.ac.uk/chalcidoids>. Access in: August, 19, 2020.

NÚÑEZ-CAMPERO, R. et al. Comparative demography of three neotropical larval-prepupal parasitoid species associated with Anastrepha fraterculus (Diptera: Tephritidae). Biological Control, 69:8-17, 2014.

ORR, D. B. Scelionid wasps as biological control agents: A review. Florida Entomologist, 71(4):506-528, 1988.

PALMA-SANTOS, M. C.; PÉREZ-MALUF, R. Comunidade de parasitoides associadas à cultura do café em Piatã, Chapada Diamantina, BA. Revista Ceres, 57(2):194-197, 2010.

PANIZZI, A. R. Wild hosts of pentatomids: Ecological significance and role in their pest status on crops. Annual Review of Entomology, 42(1):99-122, 1997.

PARRA, J. R. P. et al. Controle biológico no Brasil: Parasitoides e predadores. São Paulo, Manole, 2002. 609p.

PARRA, J. R. P.; ZUCCHI, R. A. Trichogramma in Brazil: Feasibility of use after twenty years of research. Neotropical Entomology, 33(3):271-281, 2004.

PARTELLI, F. L. et al. Microclimate and development of "Conilon" coffee intercropped with rubber trees. Pesquisa Agropecuária Brasileira, 49(11):872-881, 2014.
PERDONÁ, M. J.; CRUZ, J. C. S.; FISCHER, I. H. Cultivo consorciado de café e macadâmia. Pesquisa \& Tecnologia, 10(2):1-6, 2013.

PÉREZ-DE LA CRUZ, M. et al. Escolítidos (Coleoptera: Scolytidae) associados al agroecosistema cacao em Tabasco, México. Neotropical Entomology, 38(5):602-209, 2009.

PERIOTO, N. W. et al. Himenópteros parasitoides (Insecta, Hymenoptera) coletados em cultura de café Coffea arabica L. (Rubiaceae) em Ribeirão Preto, SP, Brasil. Arquivos do Instituto Biológico, 71(1):41-44, 2004.

PURCELL, M. F. et al. Influence of guava ripening on parasitism of the oriental fruit- fly, Bactrocera dorsalis (Hendel) (Diptera: Tephritidae), by Diachasmimorpha longicaudata (Ashmead) (Hymenoptera: Braconidae) and other parasitoids. Biological Control, 乞(4):396-403, 1994.

RIFFEL, C. T.; PRANDO, H. F.; BOFF, M. I. Primeiro relato de ocorrência de Telenomus podisi (Ashmead) e Trissolcus urichi (Crawford) (Hymenoptera: Scelionidae) como parasitoides de ovos do percevejo-do-colmodo-arroz, Tibraca limbativentris (Stal) (Hemiptera: Pentatomidae), em Santa Catarina. Neotropical Entomology, 39(3):447-448, 2010.

RODRÍGUEZ, J. L. G.; MONTILLA, R. Abundancia y diversidade de scelionidae (Hymenoptera: Platygastroidea) en plantaciones de cacao del Estado Aragua, Venezuela. ENTOMOTROPICA, 20(3):239-248, 2005.

SALGADO, B. G. et al. Produtividade de cafeeiros arborizados com ingazeiro e com grevílea em Lavras-MG. Agrossilvicultura, 1(2):155-162. 2004.

SANTOS, R. S. Surto de mariposas causa intenso desfolhamento em seringais no estado do Acre. Referência Florestal, 16(157):68-71, 2014.

SCHROTH, G. et al. Agroforestry and biodiversity conservation in tropical landscapes. Island Press, Washington, 2004. 523p.

SEGOLI, M. et al. The evolution of polyembryony in parasitoid wasps. Journal of Evolutionary Biology, 23(9):1807-1819, 2010.

SILVA, A. G. A. et al. Quarto catálogo dos insetos que vivem nas plantas do Brasil: Seus parasitas e predadores. Rio de Janeiro: Ministério da Agricultura, 2(2):1-885. 1968

SILVA, V. A. et al. Sistemas intercalares com abacaxizeiro como alternativa de renda durante a formação de cafezais irrigados. Pesquisa Agropecuária Brasileira, 47(10):1471-1479, 2012. 
SIVINSKI, J. et al. Phenological comparison of two braconid parasitoids of the caribbean fruit fly (Diptera: Tephritidae). Environmental Entomology, 27(2):360365, 1998.

SOUZA, F. F. et al. Características das principais variedades de café cultivadas em Rondônia. Porto Velho: Embrapa Rondônia, 2004, 26p.
STRAND, M. R. Polyembryony. In: RESCH, V. H.; CARDÉ, R. T. (eds) Encyclopedia of insects. Academic Press, San Diego, 2009. 1169p.

WOLLMANN, J. et al. Parasitoids of drosophilidae with potencial for parasitism on Drosophila suzukii in Brazil. Drosophila Information Service, 99:38-42, 2016. 